\title{
MENINGKATKAN HASIL BELAJAR IPA MATERI BUMI DAN ALAM SEMESTA MELALUI METODE DEMONSTRASI DI KELAS V SD NEGERI 7 RAJA TAHUN PELAJARAN 2018/2019
}

\author{
TENGKU SYAUYAH, S.Pd. SD \\ NIP. 196403231985092001
}

\begin{abstract}
Abstrak
Pendidikan adalah hal yang paling penting dalam proses berkembangnya suatu negara. Pendidikan itu sendiri merupakan suatu usaha atau kegiatan yang dijalankan dengan teratur, sistematis dan berencana dengan maksud menciptakan seseorang yang berkualitas dan berkarakter sehingga memiliki pandangan yang luas kedepan untuk mencapai cita-cita yang diharapkan dan mampu beradaptasi dalam berbagai lingkungan. Sistem pendidikan nasional di Indonesia memiliki tujuan yaitu mencerdaskan kehidupan bangsa dan mengembangkan masyarakat Indonesia seutuhnya. Tingkat keberhasilan suatu pendidikan adalah dilihat dari Hasil Belajar siswa yang telah kita ketahui melalui rapor. Sehingga menyebabkan yang dinamakan suatu urutan perolehan. Sehingga terlihat yang dinamakan prestasi dari belajar itu sendiri. Hasil Belajar yang bagus memungkinkan seorang anak bahwa dirinya adalah anak yang berhasil dalam proses belajar tersebut.

Pada pra siklus Jumlah Siswa Tuntas Belajar hanya mencapai 7 siswa, nilai rata-rata mencapai 66,66. Hasil observasi menunjukkan skor 34 Artinya Aktifitas siswa di dalam kelas kurang baik. Pada siklus I Jumlah Siswa Tuntas Belajar mencapai 17 siswa, nilai rata-rata mencapai 77,22 Artinya metode demonstrasi efektif di gunakan untuk meningkatkan prestasi belajar siswa pada materi Bumi dan Alam Semesta. Pada kegiatan observasi peserta didik, guru menilai bahwa siswa mendengarkan materi yang di sampaikan guru, siswa terlihat antusias dalam mengikuti pembelajaran IPA materi Bumi dan Alam Semesta, siswa dapat mengungkapkan pendapatnya, Siswa bertanya tentang hal-hal yang tidak di ketahui dan siswa dapat bekerja kelompok dengan teman lainnya. Hasil observasi menunjukkan skor 83 Artinya Aktifitas siswa di dalam kelas cukup baik. Akan tetapi agar lebih kondusif lagi pembelajaran IPA materi Bumi dan Alam Semesta maka peneliti hendak melaksanakan siklus II. Pada siklus II Jumlah Siswa Tuntas Belajar mencapai 22 siswa, nilai rata-rata mencapai 82,5. Artinya metode demonstrasi efektif di gunakan untuk meningkatkan prestasi belajar siswa pada materi Bumi dan Alam Semesta. Hasil observasi menunjukkan skor 107 Artinya Aktifitas siswa di dalam kelas sangat baik.
\end{abstract}

Kata Kunci: Hasil Belajar, Materi Bumi dan Alam Semesta, Metode Demonstrasi

\section{PENDAHULUAN}

Pendidikan adalah hal yang paling penting dalam proses berkembangnya suatu negara. Pendidikan itu sendiri merupakan suatu usaha atau kegiatan yang dijalankan dengan teratur, sistematis dan berencana dengan maksud menciptakan seseorang yang berkualitas dan berkarakter sehingga memiliki pandangan yang luas kedepan untuk mencapai cita-cita yang diharapkan dan mampu beradaptasi dalam berbagai lingkungan. Sistem pendidikan nasional di Indonesia memiliki tujuan yaitu mencerdaskan kehidupan bangsa dan mengembangkan masyarakat Indonesia seutuhnya.

Tingkat keberhasilan suatu pendidikan adalah dilihat dari Hasil Belajar siswa yang telah kita ketahui melalui rapor. Sehingga menyebabkan yang dinamakan suatu urutan perolehan. Sehingga terlihat yang dinamakan prestasi dari belajar itu sendiri. Hasil Belajar yang bagus memungkinkan seorang anak bahwa dirinya adalahanak yang berhasil dalam proses belajar tersebut.

Selain minat belajar, faktor intern lain yang mempengaruhi Hasil Belajar adalah aktivitas belajar. Aktivitas belajar merupakan segala kegiatan yang dilakukan dalam proses interaksi (guru dan siswa) dalam rangka menunjang keberhasilan belajar. Aktivitas yang dimaksudkan di sini penekanannya adalah pada siswa, sebab dengan adanya aktivitas siswa dalam proses pembelajaran terciptalah situasi belajar aktif, belajar aktif adalah suatu sistem belajar mengajar yang menekankan keaktifan siswa secara fisik, mental intelektual, dan emosional guna memperoleh Hasil Belajar yang berupa perpaduan antara aspek kognitif, afektif, dan psikomotor.

Salah satu materi yang di anggap sulit bagi siswa adalah materi Bumi dan Alam Semesta. Untuk meningkatkan Hasil Belajar siswa, peneliti mencoba menggunakan metode demonstrasi, Metode demonstrasi adalah Metode Demonstrasi adalah Suatu metode mengajar dimana seorang guru atau orang lain yang sengaja diminta atau murid sendiri memperlihatkan pada seluruh kelas tentang suatu proses atau suatu kaifiyah melakukan sesuatu .

Oleh karena itu guru kelas yang di sini juga berperan sebagai peneliti ingin melakukan kajian lebih dalam dengan mengambil judul "Meningkatkan Hasil Belajar IPA Materi Bumi dan Alam Semesta Melalui Metode Demonstrasi di Kelas V SD Negeri 7 Raja Tahun Pelajaran 2018/2019"

\section{TINJAUAN PUSTAKA}

A. Hasil Belajar 


\section{Pengertian Hasil Belajar}

Untuk memperoleh pengertian yang obyektif tentang Hasil Belajar, perlu dirumuskan secara jelas dari kata diatas, karena secara etimologi terdiri dari dua kata yaitu hasil dan belajar.

Menurut kamus IPA, hasil adalah suatu yang ada (terjadi) oleh suatu kerja, berhasil sukses. Menurut R.gagne hasil dipandang sebagai kemampuan internal yang menjadi milik orang serta orang itu melaksanakan sesuatu. 2

Sedangkan belajar menurut Sudjana (1996) berpendapat, belajar adalah suatu proses yang ditandai dengan adanya perubahan pada diri seseorang, perubahan sebagai hasil proses belajar dapat ditunjukkan dalam berbagai bentuk seperti perubahan pengetahuan, pemahaman, serta tingkah laku, keterampilan, kecakapan dan kebiasaan serta perubahan aspek-aspek yang ada pada individu yang belajar.

Menurut Herman Hudojo (1990), belajar merupakan kegiatan bagi setiap orang, pengetahuan, keterampilan, kegemaran dan sikap seseorang terbentuk, dimodifikasi dan berkembang disebabkan belajar.

Perbaikan dan peningkatan kualitas hasil pembelajaran dilakukan dalam bentuk remedial dan pengayaan berdasarkan hasil evaluasi hasil penilaian. Apabila dalam satu tahun waktu tertentu sebagian siswa belum mencapai tujuan pembelajaran atau kompetensi dasar, maka guru melaksanakan program remedial, sedang bagi siswa yang telah menguasai diberi program pengayaan.

Hasil Belajar siswa pada hakikiatnya adalah perubahan tingkah laku, tingkah laku sebagai Hasil Belajar dalam pengertian yang luas mencakup bidang kognitif, afektif, dan psikomotoris.

Oleh karena itu, laporan Hasil Belajar, selain muncul skor juga muncul keterangan tentang penguasaan siswa terhadap materi yang telah dipelajarai. Dengan demikian pada laporan itu selain ada ketentuan lulus atau tidak lulusnya seorang siswa juga ada keterangan materi apa saja yang sudah dikusai dan materi apa saja yang belum dikuasai oleh siswa.

\section{Tipe Hasil Belajar}

Dalam sistem dunia pendididkan nasional rumusan tujuan pendidikan, baik tujuan kurikulum maupun tujuan instruksional, menggunakan Kelasifikasi Hasil Belajar dari Benyamin Bloom yang secara garis besar membagi menjadi tiga ranah antara lain:

a. Ranah Kognitif

Pada ranah kognitif terdapat beberapa tipe Hasil Belajar diantaranya adalah:

I) Tipe Hasil Belajar pengetahuan

Tipe Hasil Belajar pengetahuan termasuk koknitif tingkat rendah yang paling rendah. Namun, tipe Hasil Belajar ini menjadi prasat bagi tipe Hasil Belajar berikutnya.

2) Tipe Hasil Belajar pemahaman

Tipe Hasil Belajar yang lebih tinggi dari pada pengetahuan adalah pemahaman dapat dijadikan menjadi tiga kategori yaitu: a) Pemahaman penterjemah, yakni menterjemahkan materi verbal dan memahami pernyataan-pernyataan non verbal.

b) Pemahaman penafsiran, yakni kemampuan untuk mengungkapkan pikiran suatu karya dan menafsirkan berbagai tipe data sosial.

c) Pemahaman ekstrapolasi, yakni kemampuan untuk mengungkapkan dibalik pesan tertulis dalam suatu keterangan atau lisan

\section{Penilaian Hasil Belajar}

untuk mengetahui dan mengevaluasi tingkat Hasil Belajar tersebut dapat dilakukan melalui tes Hasil Belajar. Berdasarkan tujuan dan ruang lingkupnya, tes Hasil Belajar dapat digolongkan kedalam jenis penilaian sebagai berikut:

1) Tes Formatif

2) Tes Subsumatif

3) Tes Sumatif

4. Faktor Yang Mempengaruhi Hasil Belajar

Adapun faktor yang mempengruhi Hasil Belajar adalah sebagai berikut:
a. Faktor Eksternal

b. Faktor Internal

\section{B. Pelajaran IPA Kelas V Materi Bumi dan Alam Semesta}

\section{Proses Pembentukan Tanah Karena} Pelapukan

\section{Jenis-jenis Batuan}

Batuan adalah merupakan salah satu dari komponen penyusun tanah. Terdapat berbagai jenis batuan dii permukaan bumi ini. Untuk masing - masing batuan mempunyai sifat dan ciri khusus. Perbedaanperbedaan pada bebatuan tersebut sangat tergantung pada kandungan dari batuan yang bersangkutan. Berikut ini adalah contoh kandungan dalam bebatuan misalnya zat besi, nikel, tembaga, emas dan bahan-bahan yang lainnya. Bahan-bahan tersebut disebut sebagai mineral.

Terbentuknya bebatuan terdapat 3 jenis batuan, antara lain : I). batuan beku (batuan magma), 2. batuan endapan (batuan sedimen), dan 3). batuan malihan (batuan metamorf).

\section{Pelapukan Batuan menjadi Tanah}

Tanah adalah merupakan hal yang sangat penting bagi makhluk hidup baik yang secara langsung maupun tidak langsung. Tanah terdiri dari bagian-bagian tertentu yang merupakan hasil dari pelapukan bahan dan juga sisa-sisa dari makhluk hidup. Pelapukan bisa terjadi disebabkan oleh karena adanya perbedaan suhu dan hujan. Pelapukan ini dikenal sebagai pelapukan fisika. Selain itu, pelapukan juga dikarenakan oleh karena makhluk hidup. Pelapukan semacam ini dikenal dengan nama pelapukan biologi. Batuan akan hancur dan lapuk bagi batuan yang mengalami pelapukan. Pelapukan tersebut terjadi selama berjuta-juta tahun.

\section{Susunan dan Jenis-jenis Tanah}

\section{a. Susunan tanah}

Pada umumnya, susunan tanah terdiri atas humus, butir tanah liat, pasir, kerikil. Seluruh bagian 
penyusun dari tanah tersebut adalah berasal dari hasil pelapukan batuan.

\section{Metode Demonstrasi \\ I. Pengertian Metode Demonstrasi}

Metode berasal dari kata "Methodos" yang secara etimologis, berasal dari bahasa latin yaitu "Methodos". Secara etimologis kata methodos berasal dari kata metha yang artinya dilalui dan hodos yang artinya jalan. Jadi methodos artinya jalan yang dilalui. Secara umum, "metode artinya jalan atau cara yang harus dilalui untuk mencapai tujuan.

Dalam kamus Inggris-Indonesia, demonstrasi yaitu .mempertunjukkan atau mempertontonkan. Metode demonstrasi adalah metode mengajar yang menggunakan peragaan untuk memperjelas suatu pengertian atau untuk memperlihatkan bagaimana melakukan sesuatu kepada anak didik.

Metode Demonstrasi adalah Suatu metode mengajar dimana seorang guru atau orang lain yang sengaja diminta atau murid sendiri memperlihatkan pada seluruh kelas tentang suatu proses atau suatu kaifiyah melakukan sesuatu.

Menurut A. Tabrani Rusyan (1993 : 106) mengatakan bahwa "Metode Demonstrasi merupakan pertunjukan tentang proses terjadinya suatu peristiwa atau benda sampai pada penampilan tingkah laku yang dicontohkan".

\section{Demonstrasi}

\section{Kelebihan dan Manfaat Metode}

Kelebihan:

- Dengan metode ini anak-anak dapat menghayati dengan sepenuh hatinya mengenai pelajaran yang diberikan.

- Memberi pengalaman praktis yang dapat membentuk perasaan dan kemuan anak.

- Perhatian anak akan terpusat kepada apa yang didemonstrasikan.

- Dengan metode ini sekaligus masalah-masalah yang mungkin timbul dalam hati anak-anak dapat langsung terjawab.

- Akan mengurangi kesalahan dalam mengambil kesimpulan, karena anak mengamati terhadap suatu proses.

\section{METODE PENELITIAN}

\section{A. Pendekatan dan Jenis Penelitian}

Pendekatan Penelitian ini menggunakan pendekatan kualitatif kuantitatif. Rancangan penelitian metode campuran (methods research design) adalah suatu prosedur untuk mengumpulkan, menganalisis, "dan mencampur" metode kuantitatif dan kualitatif dalam suatu penelitian atau serangkaian penelitian untuk memahami permasalahan penelitian (Cresswell\&Plano Clark, 20II).

Asumsi dasarnya adalah penggunaan metode kuantitatif dan kualitatif secara gabungan. Berdasarkan asumsi tersebut, memberikan pemahaman yang lebih baik tentang permasalahan dan pertanyaan penelitian daripada jika secara sendiri - sendiri.

Pada pelaksanaannya dibutuhkan ketrampilan tertentu dalam penggunaan metode ini, yaitu : (I) prosedurnya memakan banyak waktu, (2) membutuhkan pengumpulan, (3) analisis data ekstensif. Mengutip definisi yang dikemukakan oleh Stephen Kemmis seperti dikutip dalam D. Hopkins dalam bukunya yang berjudul A Teacher's Guide To Classroom Reaserch, Bristol, PA. Open University Press, 1993, halaman 44 dapat dijelaskan pengertian PTK adalah sebagai suatu bentuk kajian yang bersifat reflektif oleh pelaku tindakan, yang dilakukan untuk meningkatkan kemantapan rasional dari tindakantindakan mereka dalam melaksanakan tugas, memperdalam pemahaman terhadap tindakan-tindakan yang dilakukan itu, memperbaiki kondisi di mana praktek-praktek pembelajaran tersebut dilakukan serta dilakukan secara kolaboratif.

\section{B. Lokasi dan Waktu Penelitian}

Penelitian ini dilakukan di SD Negeri 7 Raja. Objek penelitian dilakukan di Kelas $\mathrm{V}$ yang terdiri dari 22 siswa. Penelitian ini dilakukan pada bulan Januari 2018 sampai dengan Maret 2018.

Tabel 3.I Waktu dan kegiatan penelitian

\begin{tabular}{|l|l|l|l|}
\hline Kegiatan & Jan & Feb & Mar \\
\hline Observasi Awal & & & \\
\hline $\begin{array}{l}\text { Berdiskusi dengan kepala } \\
\text { sekolah }\end{array}$ & & & \\
\hline Menyusun proposal instrument & & & \\
\hline $\begin{array}{l}\text { Menyusun } \\
\text { penelitian }\end{array}$ & & & \\
\hline Pelaksanaan siklus I & & & \\
\hline Analisis hasil siklus I & & & \\
\hline Pelaksanaan siklus II & & & \\
\hline Analisis hasil siklus II & & & \\
\hline Menyusus Laporan & & \\
\hline
\end{tabular}

\section{Subjek Penelitian}

Berikut adalah subjek penelitian: Tabel 3.2 subjek penelitian

\begin{tabular}{|c|c|}
\hline NO & NAMA \\
& \\
\hline 1 & \\
\hline 2 & \\
\hline 3 & \\
\hline 4 & \\
\hline 5 & \\
\hline 6 & \\
\hline 7 & \\
\hline 8 & \\
\hline 9 & \\
\hline 10 & \\
\hline 11 & \\
\hline
\end{tabular}




\begin{tabular}{|l|l|}
\hline 12 & \\
\hline 13 & \\
\hline 14 & \\
\hline 15 & \\
\hline 16 & \\
\hline 17 & \\
\hline 18 & \\
\hline 19 & \\
\hline 20 & \\
\hline 21 & \\
\hline 22 & \\
\hline
\end{tabular}

\section{Teknik Pengumpulan Data}

Teknik pengumpulan data yang digunakan dalam penelitian ini meliputi:

I. Observasi, digunakan untuk mengamati pelaksanaan dan perkembangan pembelajaran materi expresi yang dilakukan oleh guru dan siswa.

Pengamatan dilakukan sebelum, selama dan sesudah siklus penelitian berlangsung.

2. Tes, digunakan untuk mengetahui perkembangan atau keberhasilan pelaksanaan tindakan. Adapun bentuk tes yang diberikan kepada siswa yakni tes yang berupa menyusun kata-kata acak menjadi suatu kalimat yang benar.

3. Untuk melihat keterkaitan motivasi dan Hasil Belajar dapat dilihat dari nilai ulangan yang meningkat. Untuk itu nilai UH juga merupakan sebagai alat tes dalam pengumpulan data.

Tabel 3.3 Indikator Ketercapaian Hasil Belajar Siswa

\begin{tabular}{|c|c|c|}
\hline No & $\begin{array}{l}\text { Jenis Hasil } \\
\text { Belajar }\end{array}$ & Indikator Hasil Belajar \\
\hline $\mathrm{I}$ & $\begin{array}{l}\text { Ranah Cipta } \\
\text { (Kognitif) } \\
\text { a. Pengamatan } \\
\text { b. Ingatan } \\
\text { c. Pemahaman }\end{array}$ & 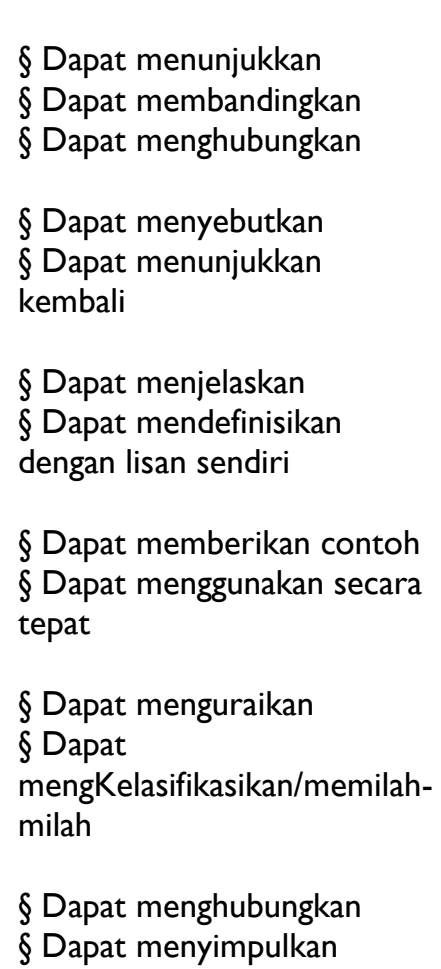 \\
\hline
\end{tabular}

\begin{tabular}{|c|c|c|}
\hline & $\begin{array}{l}\text { panduan baru } \\
\text { dan utuh) }\end{array}$ & $\begin{array}{l}\text { § Dapat menggeneralisasikan } \\
\text { (membuat prinsip umum) }\end{array}$ \\
\hline 2 & $\begin{array}{l}\text { Ranah Rasa } \\
\text { (Afektif) } \\
\text { a. Penerimaan } \\
\text { b.Sambutan } \\
\text { c. Apresiasi } \\
\text { (sikap } \\
\text { menghargai) } \\
\text { d.Internalisasi } \\
\text { (pendalaman) } \\
\text { e. Karaktirasasi }\end{array}$ & $\begin{array}{l}\text { § Mengingkari } \\
\text { § Melembagakan atau } \\
\text { meniadakan } \\
\text { § Menjelmakan dalam pribadi } \\
\text { dan perilaku sehari-hari) }\end{array}$ \\
\hline 3 & $\begin{array}{l}\text { Ranah Karsa } \\
\text { (Psikomotor)) } \\
\text { a. } \\
\text { Keterampilan } \\
\text { bergerak dan } \\
\text { bertindak } \\
\\
\text { b. Kecakapan } \\
\text { kespresi verbal } \\
\text { dan nonverbal }\end{array}$ & $\begin{array}{l}\text { § Mengkoordinasikan gerak } \\
\text { mata, tangan, kaki, dan } \\
\text { anggota tubuh lainnya } \\
\text { § Mengucapkan } \\
\text { § Membuat mimik dan } \\
\text { gerakan jasmani }\end{array}$ \\
\hline
\end{tabular}

\section{E. Teknik Analisis Data}

Metode analisis data pada penelitian ini adalah metode deskriptif yang dihitung dengan cara:

Rata-rata kelas

$$
X=\sum X
$$

$\mathrm{N}$

Keterangan:

$X=$ rata-rata kelas

$\sum X \quad=$ Jumlah nilai siswa

$\mathrm{N} \quad=$ Jumlah siswa (Sudjana, 1989)

Peningkatan prestasi hasil belajar

$$
\begin{gathered}
P=\times 2 \times 100 \% \\
X 1
\end{gathered}
$$

Keterangan: belajar

$\mathrm{P}=$ persentase rata-rata peningkatan hasil

$$
\begin{aligned}
& X 1=\text { nilai rata-rata siklus pertama } \\
& X 2=\text { nilai rata-rata siklus kedua } \\
& \text { Perhitungan ketuntasan belajar } \\
& \mathrm{K}=\sum \text { ni } X 100 \% \\
& \mathrm{~N}
\end{aligned}
$$

Keterangan: 
$\mathrm{K}=$ ketuntasan hasil belajar Kelasikal

$\sum$ ni $\quad=$ jumlah siswa tuntas belajar individu

$\mathrm{N} \quad=$ Jumlah siswa

(Sudjana, 1989)

Sedangkan untuk data pemahaman siswa yang diperoleh melalui balikan siswa diolah dengan cara mereduksi kalimatnya menjadi :

a. Hasil Belajar Siswa meningkat

b.biasa saja

c Hasil Belajar Siswa menurun

\section{HASIL PENELITIAN DAN PEMBAHASAN}

\section{A. Hasil Penelitian}

Penelitian Tindakan Kelas ini di lakukan dengan 3 siklus yakni Pra siklus, siklus I terdiri dari 2 pertemuan, pertemuan pertama di lakukan hari Selasa tanggal 6 Februari 2018, pertemuan ke 2 tanggal 7 Februari 2018.

Sedangkan siklus II juga dilakukan dengan $2 \mathrm{X}$ pertemuan, pertemuan pertama tanggal 20 Februari 2018 dan pertemuan kedua tanggal 2I Februari 2018. berikut:

Adapun rincian kegiatannya dalah sebagai

\section{Kondisi Awal (Pra Siklus )}

Pada kondisi awal peneliti belum melaksanakan metode demonstrasi. Pada pra siklus peneliti mengamati aktifitas belajar siswa dan melakukan test tentang Bumi dan Alam Semesta untuk mengetahui prestasi belajar siswa sebelum peneliti metode demonstrasi.

Berikut adalah hasil observasi peneliti terhadap aktifitas belajar siswa sebelum tindakan:

Tabel 4.I aktifitas belajar siswa pra siklus

\begin{tabular}{|c|c|c|c|c|c|c|c|c|c|c|c|c|}
\hline \multirow[t]{2}{*}{ No } & \multirow{2}{*}{$\begin{array}{l}\mathrm{N} \\
\mathrm{a} \\
\mathrm{m} \\
\mathrm{a}\end{array}$} & \multicolumn{2}{|c|}{$\begin{array}{l}\text { Aspek } \\
\text { I }\end{array}$} & \multicolumn{2}{|c|}{$\begin{array}{l}\text { Aspek } \\
2\end{array}$} & \multicolumn{2}{|c|}{$\begin{array}{l}\text { Aspek } \\
3\end{array}$} & \multicolumn{2}{|c|}{$\begin{array}{l}\text { Aspek } \\
4\end{array}$} & \multicolumn{2}{|c|}{$\begin{array}{l}\text { Aspek } \\
5\end{array}$} & \multirow{2}{*}{$\begin{array}{l}\mathrm{S} \\
\mathrm{k} \\
\mathrm{o} \\
\mathrm{r}\end{array}$} \\
\hline & & $\mathrm{Ya}$ & $\begin{array}{l}\mathrm{T} \\
\mathrm{dk}\end{array}$ & $\begin{array}{l}\mathrm{Y} \\
\mathrm{a}\end{array}$ & $\begin{array}{l}\mathrm{T} \\
\mathrm{dk}\end{array}$ & $\mathrm{Ya}$ & $\begin{array}{l}\mathrm{T} \\
\mathrm{dk}\end{array}$ & $\mathrm{Ya}$ & $\begin{array}{l}d \\
k\end{array}$ & $\mathrm{Ya}$ & $\begin{array}{l}\mathrm{T} \\
\mathrm{dk}\end{array}$ & \\
\hline I & & I & & & 0 & & 0 & & 0 & I & & 2 \\
\hline 2 & & $\mathrm{I}$ & & & 0 & & 0 & 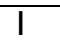 & & & 0 & 2 \\
\hline 3 & & I & & & 0 & & 0 & & 0 & & 0 & I \\
\hline 4 & & $\mathrm{I}$ & & & 0 & & 0 & & 0 & & 0 & $\mathrm{I}$ \\
\hline 5 & & I & & & 0 & & 0 & & 0 & & 0 & $\mathrm{I}$ \\
\hline 6 & & $\mathrm{I}$ & & & 0 & & 0 & & 0 & I & & 2 \\
\hline 7 & & I & & & 0 & & 0 & 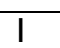 & & & 0 & 2 \\
\hline 8 & & I & & & 0 & & 0 & & 0 & & 0 & I \\
\hline 9 & & $\mathrm{I}$ & & & 0 & & 0 & & 0 & & 0 & $\mathrm{I}$ \\
\hline 10 & & $I$ & & & 0 & & 0 & & 0 & I & & 2 \\
\hline II & & $\mathrm{I}$ & & & 0 & & 0 & & 0 & & 0 & $\mathrm{I}$ \\
\hline 12 & & I & & & 0 & & 0 & & 0 & I & & 2 \\
\hline 13 & & $I$ & & & 0 & & 0 & & 0 & & 0 & $\mathrm{I}$ \\
\hline 14 & & I & & & 0 & & 0 & & 0 & & 0 & I \\
\hline 15 & & $\mathrm{I}$ & & & 0 & & 0 & & 0 & & 0 & $\mathrm{I}$ \\
\hline 16 & & I & & & 0 & & 0 & & 0 & I & & 2 \\
\hline 17 & & $\mathrm{I}$ & & & 0 & & 0 & & 0 & & 0 & $\mathrm{I}$ \\
\hline 18 & & I & & & 0 & & 0 & & 0 & & 0 & I \\
\hline 19 & & $\mathrm{I}$ & & & 0 & & 0 & & 0 & & 0 & $\mathrm{I}$ \\
\hline 20 & & I & & & 0 & & 0 & I & & & 0 & 2 \\
\hline
\end{tabular}

\begin{tabular}{|c|c|c|c|c|c|c|c|}
\hline 21 & I & 0 & 0 & 0 & I & & 2 \\
\hline 22 & I & 0 & 0 & 0 & & 0 & 1 \\
\hline \multicolumn{7}{|c|}{ Jumlah Skor } & 4 \\
\hline
\end{tabular}

Keterangan:

Aspek I: Siswa mendengarkan materi yang di sampaikan guru

Aspek 2: Siswa terlihat antusias dalam mengikuti pembelajaran IPA materi Bumi dan Alam Semesta

Aspek 3: Siswa dapat mengungkapkan pendapatnya

Aspek 4: Siswa bertanya tentang hal-hal yang tidak di ketahui

Aspek 5: Siswa dapat bekerja kelompok dengan teman lainnya

Keterangan:

Ya: I

Tidak: 0

Kriterian Nilai

Skor Maksimal Tiap siswa 5X1:5

Skor Maksimal semua siswa: 24X5: 120

Kriteria Nilai:

90-120: Aktifitas siswa di dalam kelas sangat baik

50-89: Aktifitas siswa di dalam kelas cukup baik

10-49: Aktifitas siswa di dalam kelas kurang baik

Pada pra siklus di hasilkan skor observasi 34 artinya Aktifitas siswa di dalam kelas kurang baik.

Selanjutnya peneliti merekap hasil nilai siswa pada pra siklus

Tabel 4.2 Nilai Siswa Pra Siklus

\begin{tabular}{|c|l|l|l|}
\hline NO & NAMA & Nilai & Keterangan \\
\hline I & & 70 & Tidak Tuntas \\
\hline 2 & & 60 & Tidak Tuntas \\
\hline 3 & & 60 & Tidak Tuntas \\
\hline 4 & & 60 & Tidak Tuntas \\
\hline 5 & & 60 & Tidak Tuntas \\
\hline 6 & & 50 & Tidak Tuntas \\
\hline 7 & & 70 & Tidak Tuntas \\
\hline 8 & & 80 & Tuntas \\
\hline 9 & & 80 & Tuntas \\
\hline 10 & & 70 & Tidak Tuntas \\
\hline II & & 70 & Tidak Tuntas \\
\hline 12 & & 60 & Tidak Tuntas \\
\hline I3 & & 60 & Tidak Tuntas \\
\hline I4 & & 80 & Tuntas \\
\hline I5 & & 80 & Tuntas \\
\hline I6 & & 80 & Tuntas \\
\hline 17 & & 80 & Tuntas \\
\hline 18 & & 80 & Tuntas \\
\hline 19 & & 70 & Tidak Tuntas \\
\hline 20 & & 60 & Tidak Tuntas \\
\hline 21 & & 70 & Tidak Tuntas \\
\hline 22 & & 60 & Tidak Tuntas \\
\hline Nilai Rata- & 66,66 & \\
\hline & & & \\
\hline 19
\end{tabular}




\begin{tabular}{|l|l|l|}
\hline rata & & \\
\hline \hline Jumlah Siswa & 7 & \\
Tuntas & & \\
Belajar & & \\
\hline
\end{tabular}

Selanjutnya peneliti merasa begitu penting untuk melaksanakan penelitian dengan menggunakan metode demonstrasi.

\section{Siklus I}

a. Perencanaan

Pada siklus ini di lakukan sebanyak $2 X$ pertemuan untuk itu guru menyiapkan 2 Rencana Pelaksanaan Pembelajaran (RPP). Pada setiap pertemuan di siapkan lembar kerja peserta didik (LKP) dan soal tes, untuk mengambil data tentang aktifitas guru dan peserta didik peneliti menyiapkan lembar observasi guru dan peserta didik.

b. Pelaksanaan Tindakan

Pada saat pelaksanaan tindakan guru melaksanakan proses pembelajaran mulai dari pembukaan dan sampai kegiatan ahir.

c. Observasi

Pada pengamatan peserta didik menggunakan lembar observasi yang meliputi beberapa aspek sasaran observasi meliputi:

Aspek I: Siswa mendengarkan materi yang di sampaikan guru

Aspek 2: Siswa terlihat antusias dalam mengikuti pembelajaran IPA materi Bumi dan Alam Semesta

Aspek 3: Siswa dapat mengungkapkan pendapatnya

Aspek 4: Siswa bertanya tentang hal-hal yang tidak di ketahui

Aspek 5: Siswa dapat bekerja kelompok dengan teman lainnya

Tabel 4.4 hasil Observasi Siswa Siklus I

\begin{tabular}{|c|c|c|c|c|c|c|c|c|c|c|c|c|}
\hline \multirow[t]{3}{*}{$\begin{array}{l}N \\
0\end{array}$} & \multirow{3}{*}{$\begin{array}{l}\mathrm{N} \\
\mathrm{a} \\
\mathrm{m} \\
\mathrm{a}\end{array}$} & \multicolumn{2}{|c|}{$\begin{array}{l}\text { Asp } \\
\text { ek I }\end{array}$} & \multicolumn{2}{|c|}{$\begin{array}{l}\text { Asp } \\
\text { ek } 2\end{array}$} & \multicolumn{2}{|c|}{$\begin{array}{l}\text { Asp } \\
\text { ek } 3\end{array}$} & \multicolumn{2}{|c|}{$\begin{array}{l}\text { Asp } \\
\text { ek } 4\end{array}$} & \multicolumn{2}{|c|}{$\begin{array}{l}\text { Asp } \\
\text { ek } 5\end{array}$} & \multirow[t]{3}{*}{$\begin{array}{l}\text { Sk } \\
\text { or }\end{array}$} \\
\hline & & $\mathbf{Y}$ & $\mathrm{T}$ & $\mathbf{Y}$ & $\mathrm{T}$ & $\mathrm{Y}$ & $\mathrm{T}$ & $\mathrm{Y}$ & $\mathrm{T}$ & $\mathbf{Y}$ & $\mathrm{T}$ & \\
\hline & & $\mathrm{a}$ & $\begin{array}{l}d \\
k\end{array}$ & $a$ & $\begin{array}{l}d \\
k\end{array}$ & $\mathrm{a}$ & $\begin{array}{l}d \\
k\end{array}$ & $\mathrm{a}$ & $\begin{array}{l}d \\
k\end{array}$ & $\mathrm{a}$ & $\begin{array}{l}d \\
k\end{array}$ & \\
\hline 1 & & I & & I & & & 0 & & 0 & I & & 3 \\
\hline 2 & & $I$ & & 1 & & 1 & & I & & & 0 & 4 \\
\hline 3 & & $I$ & & $I$ & & $\mathrm{I}$ & & $I$ & & & 0 & 4 \\
\hline 4 & & $I$ & & & 0 & $\mathrm{I}$ & & $\mathrm{I}$ & & 1 & & 4 \\
\hline 5 & & & 0 & & 0 & I & & $I$ & & I & & 3 \\
\hline 6 & & 1 & & 1 & & I & & I & & & 0 & 4 \\
\hline 7 & & $I$ & & 1 & & & 0 & & 0 & 1 & & 3 \\
\hline 8 & & I & & I & & & 0 & & 0 & I & & 3 \\
\hline 9 & & $I$ & & $I$ & & & 0 & & 0 & $I$ & & 3 \\
\hline 10 & & I & & 1 & & 1 & & 1 & & & 0 & 4 \\
\hline 11 & & $I$ & & 1 & & 1 & & I & & & 0 & 4 \\
\hline 12 & & I & & 1 & & 1 & & I & & & 0 & 4 \\
\hline 13 & & $I$ & & 1 & & I & & $I$ & & & 0 & 4 \\
\hline 14 & & & 0 & & 0 & 1 & & I & & 1 & & 3 \\
\hline 15 & & $I$ & & 1 & & I & & $I$ & & & 0 & 4 \\
\hline 16 & & & 0 & & 0 & 1 & & $I$ & & 1 & & 3 \\
\hline 17 & & I & & 1 & & I & & I & & & 0 & 4 \\
\hline 18 & & & 0 & & 0 & 1 & & $I$ & & 1 & & 3 \\
\hline
\end{tabular}

\begin{tabular}{|l|l|l|l|l|l|l|l|l|l|l|l|l|}
\hline I9 & & I & & I & & I & & I & & & 0 & 4 \\
\hline 20 & & & 0 & & 0 & I & & I & & I & & 3 \\
\hline 2 I & & & 0 & & 0 & I & & I & & I & & 3 \\
\hline 22 & & 0 & & 0 & I & & I & & I & & 3 \\
\hline \multicolumn{7}{|l|}{ Jumlah Skor } \\
\hline
\end{tabular}

Keterangan:

Aspek I: Siswa mendengarkan materi yang di sampaikan guru

Aspek 2: Siswa terlihat antusias dalam mengikuti pembelajaran IPA materi Bumi dan Alam Semesta

Aspek 3: Siswa dapat mengungkapkan pendapatnya

Aspek 4: Siswa bertanya tentang hal-hal yang tidak di ketahui

Aspek 5: Siswa dapat bekerja kelompok dengan teman lainnya

Ya: I

Tidak: 0

Kriterian Nilai

Skor Maksimal Tiap siswa 5X1:5

Skor Maksimal semua siswa: 24X5: 120

Kriteria Nilai:

90-120: Aktifitas siswa di dalam kelas sangat baik 50-89: Aktifitas siswa di dalam kelas cukup baik

10-49: Aktifitas siswa di dalam kelas kurang baik

d. Refleksi

Pada siklus I Jumlah Siswa Tuntas Belajar mencapai 17 siswa, nilai rata-rata mencapai 77,22 Artinya metode demonstrasi efektif di gunakan untuk meningkatkan prestasi belajar siswa pada materi Bumi dan Alam Semesta.

Pada kegiatan observasi peserta didik, guru menilai bahwa siswa mendengarkan materi yang di sampaikan guru, siswa terlihat antusias dalam mengikuti pembelajaran IPA materi Bumi dan Alam Semesta, siswa dapat mengungkapkan pendapatnya, Siswa bertanya tentang hal-hal yang tidak di ketahui dan siswa dapat bekerja kelompok dengan teman lainnya.

Hasil observasi menunjukkan skor 83 Artinya Aktifitas siswa di dalam kelas cukup baik. Akan tetapi agar lebih kondusif lagi pembelajaran IPA materi Bumi dan Alam Semesta maka peneliti hendak melaksanakan siklus II.

\section{Siklus II}

a. Perencanaan

Langkah kegiatan pada siklus II sama seperti pada siklus I, meliputi perencanaan, pelaksanaan tindakan, observasim evaluasi hasil pembelajaran dan refleksi.Perbedaannya antara siklus I dan II paa tahap pelaksanaan tindakan.

\section{B. Pembahasan}

Pelajaran IPA bagi banyak siswa menjadi beban selama menjalani masa sekolah, padahal IPA adalah ilmu 
dasar dari tingkat pendidikan dasar sampai tingkat kesulitan dalam mempelajari dan menguasai pelajaran IPA di sekolah, hal ini berefek pada rendahnya prestasi belajar IPA, begitu juga yang dialami oleh siswa SD Negeri 7 Raja khususnya di Kelas V.

Pada pra siklus Jumlah Siswa Tuntas Belajar hanya mencapai 7 siswa, nilai rata-rata mencapai 66,66. Hasil observasi menunjukkan skor 34 Artinya Aktifitas siswa di dalam kelas kurang baik.

Pada siklus I Jumlah Siswa Tuntas Belajar mencapai 17 siswa, nilai rata-rata mencapai 77,22 Artinya metode demonstrasi efektif di gunakan untuk meningkatkan prestasi belajar siswa pada materi Bumi dan Alam Semesta.

Pada kegiatan observasi peserta didik, guru menilai bahwa siswa mendengarkan materi yang di sampaikan guru, siswa terlihat antusias dalam mengikuti pembelajaran IPA materi Bumi dan Alam Semesta, siswa dapat mengungkapkan pendapatnya, Siswa bertanya tentang hal-hal yang tidak di ketahui dan siswa dapat bekerja kelompok dengan teman lainnya.

Hasil observasi menunjukkan skor 83 Artinya Aktifitas siswa di dalam kelas cukup baik. Akan tetapi agar lebih kondusif lagi pembelajaran IPA materi Bumi dan Alam Semesta maka peneliti hendak melaksanakan siklus II.

Pada siklus II Jumlah Siswa Tuntas Belajar mencapai 22 siswa, nilai rata-rata mencapai 82,5. Artinya metode demonstrasi efektif di gunakan untuk meningkatkan prestasi belajar siswa pada materi Bumi dan Alam Semesta.

Hasil observasi menunjukkan skor 107 Artinya Aktifitas siswa di dalam kelas sangat baik.

Berikut adalah grafik peningkatan prestasi belajar dari siklus I ke siklus II:

Grafik I peningkatan prestasi belajar dari Pra Slklus, siklus I ke siklus II:

\section{PENUTUP}

\section{A. Simpulan}

Pelajaran IPA bagi banyak siswa menjadi beban selama menjalani masa sekolah, padahal IPA adalah ilmu dasar dari tingkat pendidikan dasar sampai tingkat pendidikan tinggi. Realitas saat ini, banyak siswa merasa kesulitan dalam mempelajari dan menguasai pelajaran IPA di sekolah, hal ini berefek pada rendahnya prestasi belajar IPA, begitu juga yang dialami oleh siswa SD Negeri 7 Raja khususnya di Kelas V.

Pada pra siklus Jumlah Siswa Tuntas Belajar hanya mencapai 7 siswa, nilai rata-rata mencapai 66,66. Hasil observasi menunjukkan skor 34 Artinya Aktifitas siswa di dalam kelas kurang baik.

Pada siklus I Jumlah Siswa Tuntas Belajar mencapai 17 siswa, nilai rata-rata mencapai 77,22 Artinya metode demonstrasi efektif di gunakan untuk meningkatkan prestasi belajar siswa pada materi Bumi dan Alam Semesta.

Pada kegiatan observasi peserta didik, guru menilai bahwa siswa mendengarkan materi yang di sampaikan guru, siswa terlihat antusias dalam mengikuti pendidikan tinggi. Realitas saat ini, banyak siswa merasa pembelajaran IPA materi Bumi dan Alam Semesta, siswa dapat mengungkapkan pendapatnya, Siswa bertanya tentang hal-hal yang tidak di ketahui dan siswa dapat bekerja kelompok dengan teman lainnya.

Hasil observasi menunjukkan skor 83 Artinya Aktifitas siswa di dalam kelas cukup baik. Akan tetapi agar lebih kondusif lagi pembelajaran IPA materi Bumi dan Alam Semesta maka peneliti hendak melaksanakan siklus II.

Pada siklus II Jumlah Siswa Tuntas Belajar mencapai 22 siswa, nilai rata-rata mencapai 82,5. Artinya metode demonstrasi efektif di gunakan untuk meningkatkan prestasi belajar siswa pada materi Bumi dan Alam Semesta.

Hasil observasi menunjukkan skor 107 Artinya Aktifitas siswa di dalam kelas sangat baik.

\section{B. Saran}

Berdasarkan pengalaman selama melakukan penelitian tindakan kelas pada siswa Kelas V SD Negeri 7 Raja, peneliti dapat memberikan saran sebagai berikut:

I. Siswa hendaknya selalu melaksanakan pembelajaran dengan penuh tanggung jawab.

2. Orangtua hendaknya dapat melakukan kontrol dan pendampingan terhadap anak ketika sedang mengerjakan tugas yang diberikan oleh guru.

3. Guru diharapkan lebih meningkatkan bimbingan belajar kepada siswa agar Hasil Belajar siswa meningkat sehingga Hasil Belajarnya juga lebih baik.

\section{DAFTAR PUSTAKA}

Abin Syamsudin. (2009). Psikologi

Kependidikan.Bandung : PT. Remaja Rosdakarya.

Anselm,dkk, Dasar-dasar Penelitian Kualitatif

(Prosedur, Tehnik danTeori Grounded),

1997.

Penyadur Junaidi Ghony, P T Bina Ilmu, hlm. I I

Arikunto, Suharsimi, 2010. Prosedur Penelitian Suatu

Pendekatan Praktek, Jakarta: Penerbit Rineka Cipta.

Bungin, Burhan, 2003. Analisis Data Penelitian Kualitatif, Jakarta: PT Rajagrafindo Persada

Bungin, Burhan, 2007. Penelitian Kualitatif: Komunikasi, Ekonomi, Kebijakan Publik, dan IImu Sosial, Jakarta:

Kencana Prenama Media Group.

http://carapedia.com/model_pembelajaran_jigsaw_info5

87.html : Diakses pada tanggal 07 Maret 2012 http://infoini.com/2012/pengertian-metode-jigsaw.html : Diakses pada tanggal 07 Maret 2012 Silberman, Mel. 
2010. Cara Pelatihan \& Pembelajaran Aktif. Jakarta: PT

Muhibin Syah.(2004).Psikologi Pendidikan Dengan

Pendekatan Baru. Bandung: PT.Remaja Rosda karya.

Purwanto, M. Ngalim. 200I. Prinsip-Prinsip dan Teknik

Evaluasi Pengajaran, Bandung: PT. Remaja Rosdakarya

Suryabrata, Sumardi. 2002. Psikologi Pendidikan,

Jakarta: PT. Raja Grafindi Persada

Soedarsono, F.X, AplikasiPenelitian Tindakan Kelas.

Departemen Pendidikan Nasional, hlm. 2

www.kabarpendidikan.blogspot.com,www.arminaperda

na.blogspot.com,www.kmpmalang.com : Diakses pada tanggal 07 Maret 2012

Zaini, Hisyam dkk. Strategi Pembelajaran Aktif.

Yogyakarta : Pustaka Insan Madani, 2006 http:///sunartombs.wordpress.com/2009/06/15/pengerti an-dan-penerapan-metode-jigsaw: Diakses pada tanggal

07 Maret 2012

Indeks. 